\title{
The Seasonal and Spatial Distribution of Trichoptera Larvae in the Araç Creek (Kastamonu, Karabük, Turkey)
}

\author{
İbrahim KÜÇÜKBASMACI ${ }^{1 *} \oplus$, Özlem FINDIK²®
}

${ }^{1}$ Kastamonu University, Sciences and Arts Faculty, Department of Biology, Kastamonu, TURKEY ${ }^{2}$ Nevşehir Hacı Bektaş Veli University, Sciences and Arts Faculty, Department of Molecular Biology and Genetics, Nevşehir, TURKEY

*Corresponding Author: ikucukbasmaci@kastamonu.edu.tr

\section{Abstract}

Aim of study: The larvae of different insect species are used to assess water quality at various pollution levels. The aim of this study was to determine the species composition and seasonal distribution of Trichoptera larvae of the Araç Creek and relation with physicochemical parameters.

Area of study: Benthic macroinvertebrates were collected between April and October 2013 seasonally to determine the trichopteran species of the Araç Creek.

Material and method: The samples were collected using a standard dip net $(500 \mu \mathrm{m})$. The trichopteran taxa were identified using Leica APO S8 binocular stereomicroscope. Environmental variables were measured in the field using portable instruments while total hardness was measured according to the standard analytical methods.

Main results: Fifteen trichopteran taxa were identified from the Araç Creek. Three of them could be identified at the genus level. The maximum number of trichopteran larvae were collected at station 2 (311 individuals) while the fewest trichopteran were collected at station 6 (87 individuals). Hydropsyche botosaneanui was found to be the dominant species in Araç Creek.

Research highlights: A total of 1223 larvae belonging to Trichoptera were collected from the Araç Creek. 15 taxa belonging to 9 genera of 8 different families (Brachycentridae, Hydropsychidae, Hydroptilidae, Lepidostomatidae, Leptoceridae, Limnephilidae, Psychomyiidae and Rhyacophilidae) were identified. The highest number of individuals was found in the spring season.

Keywords: Trichopteran Larvae, Araç Creek, Kastamonu, Turkey

\section{Trichoptera Larvalarının Araç Çayı'nda (Kastamonu, Karabük,}

\section{Türkiye) Mevsimsel ve Mekânsal Dağılımı}

$\ddot{\mathbf{O z}}$

Çalışmanın amacı: Farklı böcek türlerinin larvaları, çeşitli kirlilik seviyelerinde su kalitesini değerlendirmek için kullanılır. Bu çalışmada, Araç Çayı'nın Trichoptera larvası tür kompozisyonunu ve mevsimsel dağılımlarını tespit etmek ve bazı fiziko-kimyasal parametrelerle ilişkisini belirlemek amaçlanmıştır.

Çalışma alanı: Araç Çayı'nın trichopteran türlerini ve trichopteran türleri ile su kalitesi arasındaki ilişkiyi belirlemek için Nisan ve Ekim 2013 arasında Bentik makro omurgasızlar mevsimsel olarak toplanmıştır.

Materyal ve yöntem: Örnekler, standart bir dip kepçesi $(500 \mu \mathrm{m})$ kullanılarak toplanmıştır. Trichoptera taksonları Leica APO S8 binoküler stereomikroskop kullanılarak teşhis edilmiştir. Çevresel değişkenler taşınabilir cihazlar kullanılarak sahada ölçülmüştür. Laboratuarda toplam sertlik standart analitik yöntemlere göre ölçülmüştür.

Temel sonuçlar: Araç çayında Trichoptera takımına ait 15 takson tespit edilmiştir. En fazla bireye 311 bireyle 2. istasyonda rastlanırken, en az bireye 87 bireyle 6. istasyonda rastlanılmıştır. Hydropsyche botosaneanui türü Araç çayında en fazla bulunan türdür.

Araştırma vurguları: Araç çayında, trichoptera takımına ait toplam 1223 larva toplanmıştır. 8 farklı familyanın (Brachycentridae, Hydropsychidae, Hydroptilidae, Lepidostomatidae, Leptoceridae, Limnephilidae, Psychomyiidae and Rhyacophilidae) 9 cinsine ait 15 takson teşhis edilmiştir. Çalışmada en fazla bireye ilkbahar mevsiminde rastlanılmıştır.

Anahtar sözcükler: Trichoptera Larva, Araç Çayı, Kastamonu, Türkiye 


\section{Introduction}

A significant portion of organic matter cycle and energy flow in freshwater systems involves insects (Cummins, 1973). Typical aquatic insects such as those from the orders Ephemeroptera, Plecoptera and Trichoptera (EPT) play a key role in assessing the ecological status of aquatic communities and in ecologic recycling (Greve et al., 1998). Several studies have stated that EPT groups provide strong responses to anthropogenic structures in aquatic ecosystems, especially in rivers (Ode et al., 2005; Bispo et al., 2006; Baptista et al., 2007; Mereta et al., 2013; Narangarvuu et al., 2015). These freshwater macroinvertebrates are severely affected by environmental pollutants on earth and are harmed by these pollutants, as sediments, industrial pollutants, mining and agricultural wastes, sewage wastes and acid rain accumulate on the water surface (Resh \& Unzicker, 1975; Resh, 1993; Dohet, 2002; Brown et al., 2007). The larvae of different insect species are used to assess water quality at various pollution levels. Trichoptera is used as a biological monitoring element to determine water quality. There are many methods for this purpose in North America, Europe and Australia (Pauls et al., 2008).

There are approximately 49 families, 616 genera and 14,548 species of the order Trichoptera known to exist worldwide (Morse, 2018). The Trichoptera fauna of Turkey was represented by 500 taxa of 22 families (461 species and 39 subspecies) (Darılmaz \& Salur, 2015; Sipahiler, 2016; Küçükbasmac1 \& Kıyak, 2017, Sipahiler, 2017a; 2017b; 2018a; 2018b). According to literature, a total of 69 taxa that belongs to Trichoptera order were recorded up to now from Kastamonu (Darılmaz \& Salur, 2015; Küçükbasmac1 \& Kıyak, 2017). Faunistic studies on Trichoptera in Turkey began in 1876. There are approximately 135 articles published by Turkish and foreign researchers since then (Darlmaz \& Salur, 2015). Numerous studies on mature trichopterans have been conducted by various authors in Turkey. However, systematic studies on the larvae are very limited, and especially the larval stage of endemic species remains unknown. The inadequate taxonomic and ecological information on benthic macroinvertebrate animals prevents the reliable use of these animals in biological observation activities. Various taxonomic groups (e.g. Ephemeroptera, Odonata, Plecoptera, Trichoptera, Simuliidae, Chironomidae) should be intensively studied at species level (Kazanc1 \& Ertunc, 2010).

The purpose of this study is to determine the species composition and seasonal distribution of Trichoptera of the Araç Creek in the West Black Sea region of Turkey and relation with physicochemical parameters.

\section{Materials and Methods}

Collection of Benthic Macroinvertebrates and Analyses of Physicochemical Parameters

The study was conducted in the basin of the Araç creek, city of Kastamonu, Western Black Sea Region (Turkey). The origin of Araç creek is in the northern slope of Ilgaz Mountains. Creek merges with Soğanlı Creek to form Yenice River (Filyos River) with other tributaries. The Araç Creek is affected by various human activities (city sewage systems, organic wastes, agricultural activities, hydroelectric power plants, sand quarries). This study was conducted at 6 stations in the Araç Creek between April and October 2013 (Figure 1). Names, coordinates and altitudes of the sampling stations are provided below (Table 1). Environmental variables (water temperature, $\mathrm{pH}$, dissolved oxygen and conductivity) were measured in the field using portable instruments (Hanna $\mathrm{pH}$ metre, oxygen metre and conductivity metre). Total hardness was measured in the laboratory according to standart analytical methods (Özdemir \& Sunlu, 1996).

Samples were collected in the stones, pebbles and plants on the ground using a standard dip net $(500 \mu \mathrm{m})$, transecting an area of $100 \mathrm{~m}^{2}$ in each station for $5 \mathrm{~min}$. Benthic macroinvertebrates were preserved in $80 \%$ ethanol after collection. In the laboratory, trichopteran species sorted from other benthic macroinvertebrates were kept in $80 \%$ ethanol. For the identification of samples, Leica APO S8 binocular stereomicroscope was used. Trichopteran species were identified using Trichoptera Families 2007 and Trichoptera 2005 package programmes 
(Lechthaler \& Stockinger, 2005; Lechthaler,

2007).

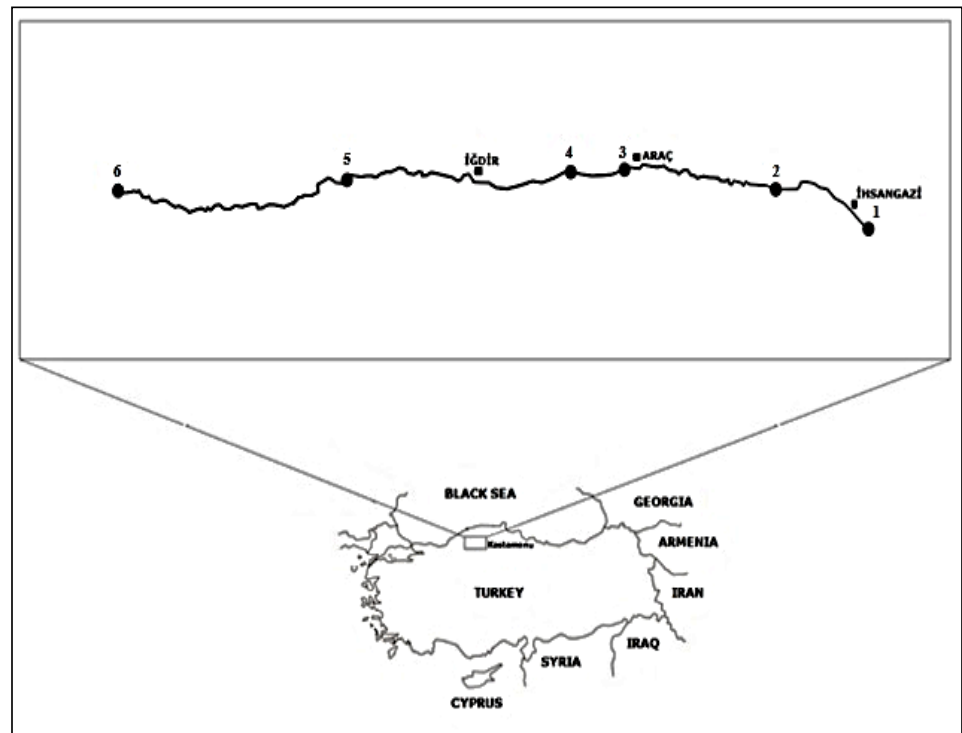

Figure 1. Sampling stations in the Araç Creek

Table 1. Details of the sampling stations

\begin{tabular}{|c|c|c|c|}
\hline $\begin{array}{l}\text { Station } \\
\text { No }\end{array}$ & Sampling station & Coordinate & $\begin{array}{l}\text { Altitude } \\
\quad(\mathrm{m})\end{array}$ \\
\hline 1 & $\begin{array}{l}\text { Kastamonu, İhsangazi, beyond } 1 \mathrm{~km} \text { from the } \\
\text { Orencik village road junction }\end{array}$ & $\begin{array}{l}41^{\circ} 10^{\prime} 39.60^{\prime \prime} \mathrm{N} \\
33^{\circ} 34^{\prime} 16.30^{\prime \prime} \mathrm{E}\end{array}$ & 920 \\
\hline 2 & $\begin{array}{l}\text { Kastamonu, İhsangazi, İhsangazi-Araç road } 7 \text { th } \mathrm{km} \text {, } \\
\text { Akkaya village road junction, the bridge vicinity }\end{array}$ & $\begin{array}{l}41^{\circ} 13^{\prime} 06.70^{\prime \prime} \mathrm{N} \\
33^{\circ} 28^{\prime} 57.50^{\prime \prime} \mathrm{E}\end{array}$ & 784 \\
\hline 3 & $\begin{array}{l}\text { Kastamonu, Araç, end of the Araç county, vicinity } \\
\text { to the gas station }\end{array}$ & $\begin{array}{l}41^{\circ} 14^{\prime} 21.13^{\prime \prime} \mathrm{N} \\
33^{\circ} 19^{\prime} 19.80^{\prime \prime} \mathrm{E}\end{array}$ & 632 \\
\hline 4 & $\begin{array}{l}\text { Kastamonu, Araç, Araç-Karabük road } 7 \mathrm{th} \mathrm{km} \text {, } \\
\text { Tatlıca village road junction, the bridge vicinity }\end{array}$ & $\begin{array}{l}41^{\circ} 14^{\prime} 08.76^{\prime \prime} \mathrm{N} \\
33^{\circ} 15^{\prime} 21.67^{\prime \prime} \mathrm{E}\end{array}$ & 594 \\
\hline 5 & $\begin{array}{l}\text { Kastamonu, Araç, Araç-Karabük road 26th km, } \\
\text { Yeşilova village }\end{array}$ & $\begin{array}{l}41^{\circ} 13^{\prime} 52.24^{\prime \prime} \mathrm{N} \\
33^{\circ} 00^{\prime} 22.95^{\prime \prime} \mathrm{E}\end{array}$ & 432 \\
\hline 6 & Karabük, Safranbolu, Navsaklar village & $\begin{array}{l}41^{\circ} 12^{\prime} 56.85^{\prime \prime} \mathrm{N} \\
32^{\circ} 44^{\prime} 14.81^{\prime \prime} \mathrm{E}\end{array}$ & 301 \\
\hline
\end{tabular}

\section{Data Analysis}

The mean and standart deviations of parameters have been calculated in according to seasons and stations. Differences of stations and seasons were determined by student $t$ test methods $(p<0.01)$. Correlation analysis was also conducted to evaluate the relationship between physicochemical parameters and Trichoptera abundance.

\section{Results}

Physical and Chemical Variables

All stations except station 6 had similar benthic substrate (little rocks, rubbles, pebbles, gravels and sands). The substrates were approximately $2-20 \mathrm{~cm}$ in size and were categorised as micro-/mesolithal. Station 6 had a base structure composed of boulders followed by rubbles and shingles. The substrate of station 6 was approximately $>20 \mathrm{~cm}$ in size, and it was categorised as macro-/megalithal. Station 1 falls in the category of g8h (altitude above sea level is $>800 \mathrm{~m}$ ) with an altitude of $920 \mathrm{~m}$, based on the parameter of "Water Framework Directive (WFD) altitude preference". Other stations withaltitudes of $301-784 \mathrm{~m}$ were categorised as $28 \mathrm{~h}$ (altitude above sea level is 200-800 m) (Graf, 2002). 
In our study, distribution of seasonal physicochemical parameters are shown in the Table 2. The evaluation of the physicochemical results were made based on Regulation on the Amendment of Surface Water Quality Regulation of Official Gazette dated 10.08.2016 No. 29797 (Regulation on the Amendment of Surface Water Quality Regulation, 2016). Changes of the seasonal for water temperature and dissolved oxygen were found statistically important $(p<0.01)$. Statistical differences have not been observed for the $\mathrm{pH}$, conductivity and total hardness.

Table 2. Concentrations of physicochemical values of the Araç Creek according to the seasons by mean value, standard deviation and min-max

\begin{tabular}{clccccc} 
Season & pH & $\begin{array}{c}\text { Water } \\
\text { Temperature } \\
\left({ }^{\circ} \mathrm{C}\right)\end{array}$ & $\begin{array}{c}\text { Conductivity } \\
(\mu \mathrm{S} / \mathrm{cm})\end{array}$ & $\begin{array}{c}\text { Dissolved } \\
\text { Oxygen } \\
(\mathrm{mg} / \mathrm{L})\end{array}$ & $\begin{array}{c}\text { Total } \\
\text { Hardness }\end{array}$ \\
\hline \multirow{2}{*}{ Spring } & Mean $\pm \mathrm{SD}$ & $8.34 \pm 0.19$ & $16.39 \pm 3.16$ & $714.00 \pm 17.65$ & $10.23 \pm 0.30$ & $20.22 \pm 2.19$ \\
& Min & 8.10 & 11.30 & 687.10 & 9.95 & 16.00 \\
& Max & 8.70 & 20.20 & 736.20 & 10.80 & 22.80 \\
\hline \multirow{3}{*}{ Summer } & Mean $\pm \mathrm{SD}$ & $8.20 \pm 0.21$ & $22.02 \pm 2.51$ & $716.86 \pm 15.20$ & $8.49 \pm 0.62$ & $23.03 \pm 4.69$ \\
& Min & 8.00 & 17.60 & 698.40 & 8.00 & 16.00 \\
& Max & 8.60 & 25.30 & 737.50 & 9.58 & 28.80 \\
\hline \multirow{3}{*}{ Autumn } & Mean $\pm \mathrm{SD}$ & $8.34 \pm 0.31$ & $12.74 \pm 3.03$ & $717.87 \pm 17.68$ & $10.26 \pm 0.64$ & $21.88 \pm 3.97$ \\
& Min & 7.90 & 7.00 & 690.20 & 9.30 & 16.00 \\
& Max & 8.80 & 16.40 & 740.20 & 11.31 & 28.40 \\
\hline F & & 1.001 & $24.676^{* *}$ & 0.165 & $16.724 * *$ & 0.827 \\
\hline
\end{tabular}

Table 3. Quality criteria of continental surface water resources according to their classes in terms of chemical and physicochemical parameters

\begin{tabular}{lcccc}
\hline Parameters & I (Very Good) & II $($ Good $)$ & III (Modarate) & IV $($ Bad $)$ \\
\hline $\mathrm{pH}$ & $6-9$ & $6-9$ & $6-9$ & $6-9$ \\
\hline Conductivity $(\mu \mathrm{S} / \mathrm{cm})$ & $<400$ & 1000 & 3000 & $>3000$ \\
\hline Dissolved Oxygen $(\mathrm{mg} / \mathrm{L})$ & $>8$ & 6 & 3 & $<3$ \\
\hline
\end{tabular}

According to the Regulation on Surface Water Quality of Official Gazette dated 10.08.2016 No. 29797, the mean $\mathrm{pH}$ value and dissolved oxygen concentration determined for the Araç Creek indicates that the water quality of the Araç Creek is Class I - High quality water (which describes the water quality as "very good"), whereas the conductivity values indicate a water quality of Class II - Slightly polluted water (which describes the water quality as "Good") (Table 3).

The lowest concentration of the total hardness was determined at the station 1 , however the highest concentration was measured at the station 2. According to French Degree of Hardness, the Stations 1, 3 and 5 were found as moderately hard water and stations 2, 4 and 6 were determined hard water.
The correlation between some physicochemical parameters and Trichoptera larvae were determined by using Pearson correlation analysis and the results are shown in Table 4. Environmental factors such as water temperature affect the abundance of trichopterans. According to the results, there is a negative correlation between trichopteran abundance and water temperature $(\mathrm{r}=-482$, $\mathrm{p}<0.05)$. Correlation of between other parameters and trichoptera abundances have not been observed. While Hydropsyche contubernalis was positively correlated $(\mathrm{r}=0.710, \quad \mathrm{p}<0.01) \quad$ with conductivity, Micrasema spp. showed negative correlation $(\mathrm{r}=-0.511, \mathrm{p}<0.05)$. Also $H$. contubernalis were positively correlated with total hardness $(0.0547, \mathrm{p}<0.05)$. 
Table 4. Correlation matrix between physicochemical parameters and Trichoptera abundance

\begin{tabular}{lccccc}
\hline & $\mathrm{pH}$ & $\begin{array}{c}\text { Water } \\
\text { Temperature } \\
\left({ }^{\circ} \mathrm{C}\right)\end{array}$ & $\begin{array}{c}\text { Conductivity } \\
(\mu \mathrm{S} / \mathrm{cm})\end{array}$ & $\begin{array}{c}\text { Dissolved } \\
\text { Oxygen } \\
(\mathrm{mg} / \mathrm{L})\end{array}$ & $\begin{array}{c}\text { Total } \\
\text { hardness }\end{array}$ \\
\hline Abundance of Trichoptera & 0.162 & $\mathbf{- 0 . 4 8 2 *}$ & -0.370 & 0.236 & -0.070 \\
\hline Rhyacophila nubila (Zetterstedt, 1840) & -0.102 & 0.336 & -0.271 & -0.310 & 0.182 \\
\hline Rhyacophila spp. & -0.311 & 0.102 & 0.000 & 0.000 & 0.069 \\
\hline Hydroptila spp. & -0.284 & 0.397 & 0.210 & -0.304 & 0.401 \\
\hline Psychomyia pusilla (Fabricius, 1781) & -0.069 & 0.341 & 0.375 & 0.068 & 0.103 \\
\hline Cheumatopsyche lepida (Pictet, 1834) & 0.069 & -0.013 & 0.112 & 0.414 & -0.232 \\
\hline $\begin{array}{l}\text { Hydropsyche botosaneanui Marinković- } \\
\text { Gospodnetić, 1966 }\end{array}$ & 0.131 & -0.133 & -0.291 & 0.352 & -0.411 \\
\hline Hydropsyche bulbifera McLachlan, 1878 & -0.115 & 0.193 & -0.119 & 0.076 & -0.123 \\
\hline $\begin{array}{l}\text { Hydropsyche contubernalis } \text { McLachlan, } \\
\text { 1865 }\end{array}$ & -0.278 & 0.195 & $\mathbf{0 . 7 1 0 * *}$ & -0.103 & $\mathbf{0 . 5 4 7 *}$ \\
\hline Hydropsyche exocellata Dufour, 1841 & -0.154 & 0.221 & 0.399 & 0.014 & 0.396 \\
\hline Hydropsyche instabilis (Curtis, 1834) & 0.050 & -0.224 & -0.278 & 0.250 & -0.255 \\
\hline Hydropsyche pellucidula (Curtis, 1834) & 0.401 & -0168 & -0.041 & 0.396 & -0.240 \\
\hline Micrasema spp. & -0.052 & 0.068 & $\mathbf{- 0 . 5 1 1 *}$ & 0.119 & -0.241 \\
\hline Lepidostoma hirtum (Fabricius, 1775) & -0.284 & 0.117 & -0.304 & 0.023 & 0.024 \\
\hline Limnephilus lunatus Curtis, 1834 & 0.047 & 0.164 & 0.164 & 0.210 & -0.047 \\
\hline Setodes viridis (Fourcroy, 1785) & -0.284 & 0.397 & 0.210 & -0.304 & 0.401 \\
\hline
\end{tabular}

\section{Trichopteran Taxa}

A total of 1223 larvae belonging to Trichoptera were collected from the Araç Creek between April and October 2013. 15 taxa belonging to 9 genera of 8 different families (Brachycentridae, Hydropsychidae, Hydroptilidae, Lepidostomatidae, Leptoceridae, Limnephilidae, Psychomyiidae and Rhyacophilidae) were identified. The identified trichoptera species are listed in
Table 5. Seasonal distribution of trichoptera larvae were shown in Table 6. Fifteen trichopteran taxa were identified from the Araç Creek that part of Filyos River system. Three of them could be identified at the genus level. The maximum number of trichopteran were collected at station 2 (311 individuals) while the fewest trichopteran were collected at station 6 (87 individuals).

Table 5. Trichopteran taxa list and abundance (ind. $/ \mathrm{m}^{2}$ ) from the Araç Creek

\begin{tabular}{|c|c|c|c|c|c|c|c|c|}
\hline \multirow{2}{*}{ Family } & \multirow{2}{*}{ Taxa } & \multirow{2}{*}{$\begin{array}{c}\text { Number of } \\
\text { Larvae }\end{array}$} & \multicolumn{6}{|c|}{ Sampling Station } \\
\hline & & & 1 & 2 & 3 & 4 & 5 & 6 \\
\hline \multirow{2}{*}{ Rhyacophilidae } & R. nubila & 13 & 11 & 1 & & & 1 & \\
\hline & Rhyacophila spp. & 2 & & 1 & & & & 1 \\
\hline Hydroptilidae & Hydroptila spp. & 3 & & & & & 3 & \\
\hline Psychomyiidae & P. pusilla & 4 & & & & & 2 & 2 \\
\hline \multirow{7}{*}{ Hydropsychidae } & C. lepida & 4 & & & & 3 & 1 & \\
\hline & H. botosaneanui & 665 & 223 & 200 & 187 & 22 & 15 & 18 \\
\hline & H. bulbifera & 250 & 9 & 52 & 19 & 63 & 106 & 1 \\
\hline & H. contubernalis & 87 & & & & 3 & 21 & 63 \\
\hline & H. exocellata & 6 & & & & 6 & & \\
\hline & H. instabilis & 64 & & 54 & 7 & 3 & & \\
\hline & H. pellucidula & 119 & 26 & & 72 & 5 & 14 & 2 \\
\hline Brachycentridae & Micrasema spp. & 2 & 1 & 1 & & & & \\
\hline Lepidostomatidae & L. hirtum & 2 & & 2 & & & & \\
\hline Limnephilidae & L. lunatus & 1 & & & & & 1 & \\
\hline Leptoceridae & S. viridis & 1 & & & & & 1 & \\
\hline
\end{tabular}


Distribution of percentage of trichoptera species with $42.00 \%$ in station 6. species are shown in Figure 2. $H$. Additionally, in station 4 and $6, H$. botosaneanui was found to be the dominant species in station 1,2 and 3 with $82.59 \%$, $64.31 \%, 65.61 \%$ respectively. In station 4 and $5, H$. bulbifera was the dominant species with $58.33 \%, 56.99 \%$ respectively. $H$. contubernalis was observed the dominant

botosaneanui was found to be the 2 th species with $20.37 \%$ and $12.00 \%$ respectively.

In spring, the mean abundance (1082 ind. $/ \mathrm{m}^{2}$ ) was higher than in other seasons (Table5).

Table 6. Seasonal distribution of Trichoptera larvae (ind. $/ \mathrm{m}^{2}$ )

\begin{tabular}{llccc}
\hline \multicolumn{1}{c}{ Family } & \multicolumn{1}{c}{ Taxa } & Spring & Summer & Autumn \\
\hline \multirow{2}{*}{ Rhyacophilidae } & R. nubila & 11 & 2 & \\
& Rhyacophila spp. & 2 & & \\
\hline Hydroptilidae & Hydroptila spp. & & 3 & \\
\hline Psychomyiidae & P. pusilla & 2 & 2 & \\
\hline & C. lepida & 4 & & 57 \\
& H. botosaneanui & 665 & & 6 \\
& H. bulbifera & 187 & 63 & 5 \\
Hydropsychidae & H. contubernalis & 28 & 2 & \\
& H.exocellata & & & \\
\hline H. instabilis & 64 & & \\
\hline Lepidostomatidae & H. pellucidula & 114 & & \\
\hline Limnephilidae & L. lunatus & 2 & & \\
\hline Leptoceridae & S. viridis & 2 & & \\
\hline
\end{tabular}




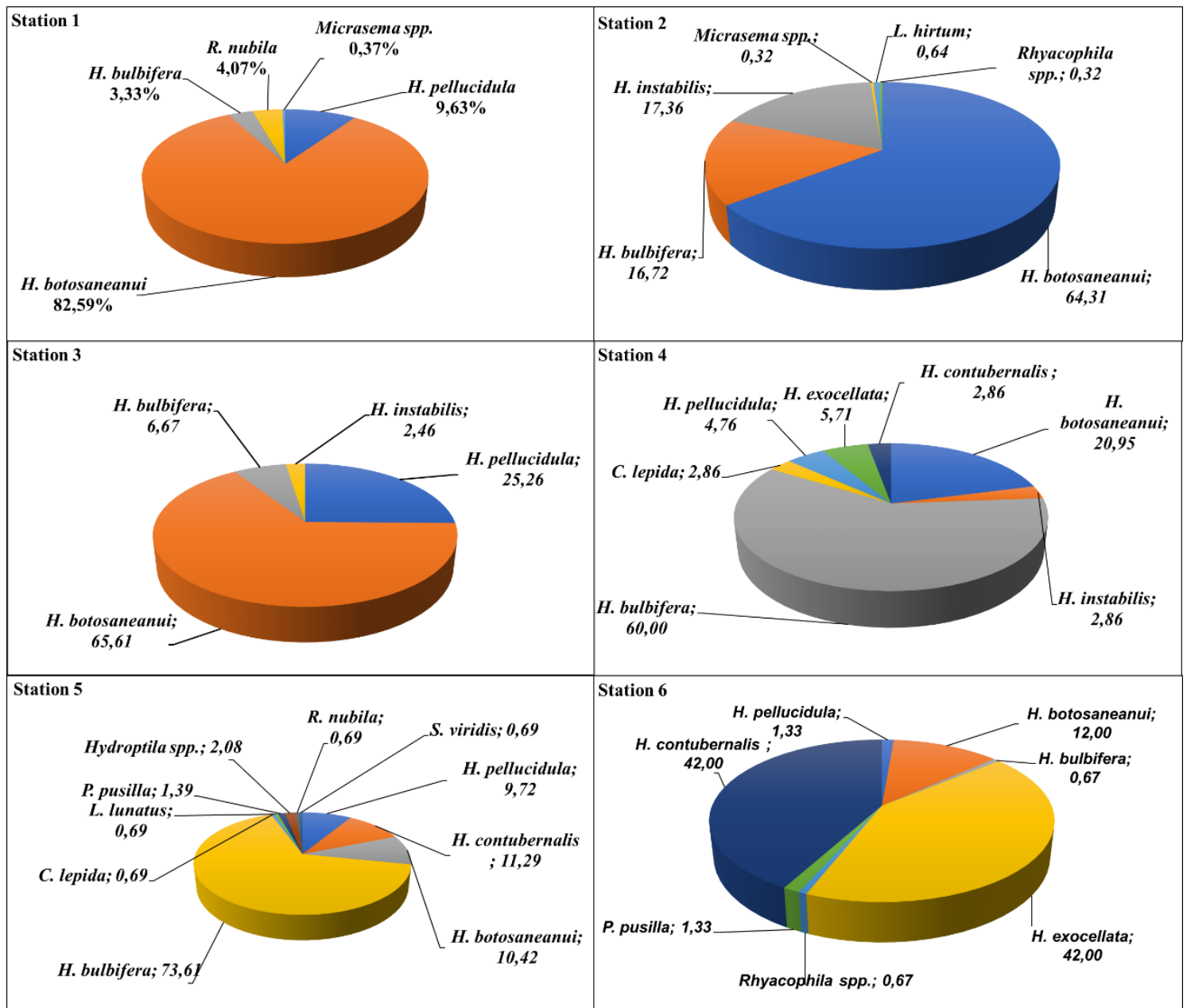

Figure 2. Composition of Trichoptera species according to the stations

\section{Discussion}

As a results of the study, 15 taxa belonging to Trichoptera order were determined in Araç creek (Turkey). According to previous studies, Hydropsychidae is regarded as a very tolerant family all over the world, with species being segregated within different water quality characteristics along the river (Bonada et al. 2004; Edington \& Hildrew, 1981). Hydropsychidae $(97,71 \%)$ was the main families found in our study.

Pirvu \& Pacioglu (2012) reported that the caddisflies reflect a strong affinity for high and low altitude sites, as for pristine and polluted areas of the river. However, Skuja \& Spungis (2010) state that the abundance of caddisflies varied along the stream continuum (longitudinal gradient) and the abundance was low in the upper altitudes, high in the middle altitudes, and varied within a wide range in the lower altitudes.
The station sequence of the abundance of trichopteran larvae in this study was as follows; 2.> 3.> 1.> 5.> 4.> 6. The largest number of caddisfly larvae were sampled at Station 2, followed by Station 3 while the least number of larvae were collected at station 6. Station 6 is defined as the section of the Arac Creek flowing through the south of Navsaklar village of Safranbolu district, Karabük. This sampling site is still being strongly influenced by human-induced effects such as continuous agricultural effluents, domestic waste. In addition, this station consists of large rocks and stagnant waters at which the flow rate decreases and the temperature is higher in all seasons than in the other stations. Schmera \& Eros (2004) indicated that the combined effect of season, stream order and riverbed morphology showed a significant influence on caddisfly assemblages. 
In the studied river the highest number of trichopteran larvae was noted in the samples collected in spring. The life cycle of the species is the main reason for the increase in the number of individuals in the spring (Demirsoy, 1996). Similarly, in the study done by Van den Brink et al. (2013), trichopteran larvae were the most numerous in the early spring. In the spring samples, the greater variety and abundance of Hydropsychidae was noted in comparison with the other seasons samples.

The studies showed that physical and chemical parameters of environmental such as hydrology, geographical location, climatic factors and physicochemical variables of water are factors which influence the composition of trichopteran larvae (Skuja \& Spungigis, 2010; Lock \& Goethals, 2012). Recent researches, have reported that water temperature, dissolved oxygen, altitude, depth, flow rate and suspended sediment have an impact on trichopteran density (Hughes, 2006; Pirvu \& Pacioglu, 2012; Rogowski \& Stewart, 2016; Zeybek \& Koşal Şahin, 2016; Hasmi et al. 2017). Abundance of Trichoptera is affected easily by dissolved oxygen fluctuation, due to the fact that tricoptera is gill-breathing insects (Narangarvuu et al., 2015). In our study, we observed a correlation between trichopteran density and water temperature. Water temperature is an important factor in distribution of Trichoptera larvae (Urbanič, 2006). It is also known that larval development of trichoptera species is affected by the temperature alterations due to hydroelectric power production (Frutiger, 2004).

In our study, conductivity is lower in the first three stations (2, 3 and 1.station) where abundance is highest compared to other stations. Caddisflies also did not tolerate high conductivities and were hardly found at conductivities above $1000 \mathrm{mS} . \mathrm{cm} x 1$ (Lock \& Goethals, 2012).

\section{Conclusions}

As a result of this work, 15 taxa belonging to 9 genera of 8 families (Brachycentridae, Hydropsychidae, Hydroptilidae, Lepidostomatidae,
Leptoceridae, Limnephilidae, Psychomyiidae, Rhyacophilidae) were identified in 6 stations of Araç Creek. The highest abundance of trichoptera larvae were dominant in the first 3 stations, whereas lower abundance were detected in stations 4 and 5, and that the lowest abundance of trichopteran larvae was detected in station 6 .

\section{Acknowledgement}

This study has been supported within the scope of project numbered KUBAP-01/ 2012-10 by Kastamonu University, Scientific Research Projects Coordination Department.

\section{References}

Baptista, D. F., Buss, D. F., Egler, M., Giovanelli, A., Silveira, M. P. \& Nessimian, J. L. (2007). A multimetric index based on benthic macroinvertebrates for evaluation of Atlantic Forest streams at Rio de Janeiro State, Brazil. Hydrobiologia, 575(1), 83-94.

Bispo, P. D. C., Oliveira, L. G., Bini L. M. \& Sousa, K. G. D. (2006). Ephemeroptera, Plecoptera and Trichoptera assemblages from riffles in mountain streams of Central Brazil: environmental factors influencing the distribution and abundance of immatures. Brazilian Journal of Biology, 66(2B), 611622.

Bonada, N., Zamora-Muñoz, C., Rieradevall, M. \& Prat, N. (2004). Trichoptera (Insecta) collected in Mediterranean river basins of the Iberian Peninsula: taxonomic remarks and notes on ecology. Graellsia, 60(1), 41-69.

Brown, L. E., Hannah, D. M. \& Milner, A. M. (2007). Vulnerability of alpine stream biodiversity to shrinking glaciers and snowpacks. Global Change Biology, 13(5), 958-966. http://dx.doi.org/10.1111/j.13652486.2007.01341.x

Cummins, K. W. (1973). Trophic relations of aquatic insects. Annual Review of Entomology, 18, 183-206. https://doi.org/10.1146/annurev.en.18.010173. 001151

Darılmaz, M. C. \& Salur, A. (2015). Annotated catalogue of the Turkish caddisflies (Insecta: Trichoptera). Munis Entomology \& Zoology, 10(Suppl.), 521-734.

Demirsoy, A. (1996). Genel ve Türkiye Zoocoğrafyası "Hayvan Coğrafyası, Meteksan A.Ş., Ankara, 630.

Dohet, A. (2002). Are caddisflies an ideal group for the biological assessment of water quality in streams? Nova Supplementa Entomologica 
(Proceedings of the 10th International Symposium on Trichoptera) 15, 507-520.

Edington, J. M \& Hildrew, A. G. (1981). Caseless caddis larvae of the British isles., Freshwater Biological Association, 43, 91.

Frutiger, A. (2004). Ecological impacts of hydroelectric power production on the River Ticino. Part 2: Effects on the larval development of the dominant benthic macroinvertebrate (Allogamus auricollis, Trichoptera), Archiv für Hydrobiologie, 159(1), 57-75.

Greve, G. D., van der Geest, H. G., Stuijfzand, S. C., Engels, S. \& Kraak, M. H. S. (1998). Development of ecotoxicity tests using laboratory reared larvae of the riverine caddisflies Hydropsyche angustipennis and Cyrnus trimaculatus. Proceedings of the Section Experimental and Applied Entomology, Netherlands Entomological Society, 9, 205-210.

Hasmi, N. A., Ramlan, N., Musa, N. N. \& Faizzainuddin, M. A. (2017). Influence of Physicochemical parameters on abundance of Aquatic Insects in Rivers of Perak, Malaysia. Proceedings of 72nd IASTEM International Conference September 5-6, 2017. Melbourne, Australia, 1-5.

Hughes, S. J. (2006). Temporal and spatial distribution patterns of larval trichoptera in Madeiran streams. Hydrobiologia, 553(1), 2741. http://dx.doi.org/10.1007/s10750-0050627-1

Kazanc1, N. \& Ertunc, O. (2010). Use of Simuliidae (Insecta, Diptera) species as indicators of aquatic habitat quality of Yeşilırmak River Basin (Turkey). Review of Hydrobiology, 3(1), 27-36.

Küçükbasmacı, İ. \& Kiyak, S. (2017). A study on the caddisfly fauna (Insecta: Trichoptera) of Kastamonu and a new species record for Turkey. Munis Entomology \& Zoology, 12(2), 486-499.

Lechthaler, W. (2007). Trichoptera families: key to larvae from central Europe [DVD], Eutaxa.

Lechthaler, W. \& Stockinger, W. (2005). Trichoptera: key to larvae from central Europe [DVD], Eutaxa.

Lock, K. \& Goethals, P. L. M. (2012). Distribution and ecology of the caddisflies (Trichoptera) of Flanders (Belgium), Annales de Limnologie-International Journal of Limnology, 48, 31-37.

Mereta, S. T., Boets, P., De Meester, L. \& Goethals, P. L. (2013). Development of a multimetric index based on benthic macroinvertebrates for the assessment of natural wetlands in Southwest Ethiopia.
Ecological Indicators, 29, 510-521. https://doi.org/10.1016/j.ecolind.2013.01.026

Morse, J. C. (Ed.) (2018). Trichoptera World Checklist. Retrieved from http://entweb.clemson.edu/database/trichopt/i ndex.htm (Accessed date: October 2018).

Narangarvuu, D., Oyunbileg, J., Yang, P. S. \& Boldgiv, B. (2015) Distribution of Ephemeroptera, Plecoptera, and Trichoptera assemblages in relation to environmental variables in headwater streams of Mongolia. Environmental Earth Sciences, 73(2), 835847.

Ode, P. R., Rehn, A. C. \& May, J. T. (2005). A quantitative tool for assessing the integrity of southern coastal California streams. Environmental management, 35(4), 493-504. https://doi.org/10.1007/s00267-004-0035-8

Özdemir, E. \& Sunlu, U. (1996). Su Kalitesi. (II.Baskı). İzmir: Ege Üniversitesi Basımevi.

Pauls, S. U., Graf, W., Haase, P., Lumbsch, H. T. \& Waringer, J. (2008). Grazers, shredders and filtering carnivores--the evolution of feeding ecology in Drusinae (Trichoptera: Limnephilidae): insights from a molecular phylogeny. Molecular Phylogenetics and Evolution, 46, 776-791. https://doi.org/10.1016/j.ympev.2007.11.003

Pirvu, M. \& Pacioglu, O. (2012). The ecological requirements of caddisflies larvae (Insecta: Trichoptera) and their usefulness in water quality assessment of a river in south-west Romania. Knowledge and Management of Aquatic Ecosystems, (407), 03. https://doi.org/10.1051/kmae/2012029

Regulation on the Amendment of Surface Water Quality Regulation (in Turkish) (2016). Official Gazette (No: 29797). Retrieved from http://www.resmigazete.gov.tr/eskiler/2016/08 120160810-9-1.pdf (Accessed date: October 2019).

Resh, V. H. (1993). Recent trends in the use of Trichoptera in water quality monitoring. (Editor Otto C. In: Proceedings of the 7th International Symposium on Trichoptera) Backhuys Publishers, Leiden, The Netherlands. 285-291.

Resh, V. H. \& Unzicker, J. D. (1975). Water quality monitoring and aquatic organisms: the importance of species identification. Journal Water Pollution Control Federation, 47, 9-19.

Rogowski, D. L. \& Stewart, K. R. (2016). Effects of increased temperature on a Trichoptera (Hydropsychidae) from premontane forest streams in Southern Costa Rica. Tropical Ecology, 57(1), 57-68.

Schmera D. \& Eros T. (2004). Effect of riverbed morphology, stream order and season on the 
structural and functional attributes of caddisfly assemblages (Insecta: Trichoptera), Annales de Limnologie-International Journal of Limnology, 40, 193-200.

Skuja, A. \& Spungisis, V. (2010). Influence of environmental factors on the distribution of caddisfly (Trichoptera) communities in mediumsized lowland streams in Latvia, Estonian Journal of Ecology, 59 (3), 197.215.

Sipahiler, F. (2016). Two new species of Trichoptera (Psychomyiidae, Beraeidae) from Turkey. Nova Acta Científica Compostelana (Bioloxía), 23, 61-64.

Sipahiler, F. (2017a). Four new species of the genus Kelgena Mey from Turkey (Trichoptera: Limnephilidae, Chaetopterygini). Nova Acta Cientifica Compostelana (Bioloxía), 24, 13-20.

Sipahiler, F. (2017b). Descriptions of two new species of the genus Psilopteryx Stein from Turkey (Trichoptera, Limnephilidae, Chaetopterygini). Nova Acta Científica Compostelana (Bioloxía), 24, 69-73.

Sipahiler, F. (2018a). Three new species of caddisflies (Trichoptera: Hydroptilidae, leptoceridae) from Turkey and faunistic list for the Seyhan and Ceyhan rivers. Nova Acta Científica Compostelana (Bioloxía), 25, 3743.

Sipahiler, F. (2018b). Studies on the males of the genus Philopotamus Leach in Turkey (Trichoptera, Philopotamidae). Nova Acta Cientifica Compostelana (Bioloxía), 25, 5570.

Urbanič G. (2006). Distribution and structure of Trichoptera assemblages in the ecoregion Hungarian lowland in Slovenia. Proceedings of the 36th International Conference of the International Association for Danube Research September 4-8, 2006. Vienna, Klosterneuburg, Austria, 285- 289.

Van den Brink, F.W.B., Van der Velde, G., \& Wijnhoven, S. (2013). Seasonal changes in caddisfly larval assemblages in riverfloodplain habitats along a connectivity gradient, Hydrobiologia, 716(1), 75-85.

Zeybek, M. \& Koşal-Şahin, S. (2016). The Distribution of Trichoptera Assemblages In Relation To Environmental Variables in the Streams of Tunceli (Turkey). Fresenius Environmental Bulletin, 25(11), 4972-4981. 